\title{
O Código de Processo e a Justiça de Paz
}

\author{
Miguel Reale
}

Agora que se cogita da modificação da lei de organização judiciária do Estado, não é demais analisar a conveniência de se restabelecer a competência da Justiça de paz para julgar ações até uma certa alçada. Essa medida teria, a nosso ver, a vantagem de des, congestionar os serviços dos Juizes de Direito, hoje em dia sobrecarregados de atribuições. Embora não tenhamos conhecimentos de estatísticas a respeito, não será desarrazoado crer que uma bôa percentagem das audiências de instrução e julgamento se destina à decisão de ações de valor inferior a 1:000\$000.

Essa situação redunda não só em um atrazo, que vai assustadoramente crescendo, na designação das audiências, como torna excessivas as despesas judiciais dos pequenos feitos, de tal maneira que muitos são os que preferem não fazer valer os seus direitos quando sabedores de que o dispêndio com as custas poderá superar o valor do pedido. Dess'arte, a vantagem de um julgamento mais criterioso se torna praticamente inexistente, tais os tropeços de ordem material.

Ora, quer nos parecer que a fixação da competência da Justiça de paz, com recurso de suas decisões para a Justiça tógada, viria, de um lado, resolver, em parte, a questão do acúmulo das audiências a cargo dos Juizes de Direito, e, do outro, diminuir as despezas dos processos.

Entretanto, pode parecer, à vista dos artigos 839 e seus parágrafos e 840 do Código de Processo, ser vedado coñferir aos Juizes de paz competência para processar e julgar ações de valor igual ou inferior a 2:000\$00, visto como tais ações são declaradas da competência dos Juizes de Direito, devendo os respectivos embargos de nulidade ou infringente de julgado e de declaração ser deduzidos perante o mesmo Juizo. A idéia, por conseguinte, de uma Justiça de paz com determinada competência e recurso de suas decisões à Justiça togada, resultaria impossível "ex-vi" da lei processual. 
Somos, porém, de opinião que, nêsse ponto, o Código de Processo se choca com um dispositivo expresso da Constituição de 10 de Novembro, cujo artigo 104 dispõe: "Os Estados poderão criar * Justiça de paz eletiva, fixando-lhe a competência, com a ressalva do recurso das suas decisões para a Justiça togada".

Em verdade, é preciso notar que a Constituição de 10 de Novembro de 1937. não realizou senão a unificação do Direito Processual, já anteriormente consagrada pela Constituição de 1934, sem privar os Estados da competência privativa de legislar sôbre a sua divisão e organização judiciária. Ao contrário, a Constituição vigente assegura, da maneira mais cristalina, a autonomia estadual no que concerne à divisão e organização de seus órgãos judicantes, determinando apenas a observância de certos principios.

Examinando-se os artigos 91, 92 e 103 da Constituição Federal, verifica-se que a Lei Magna reconhece a competência privativa dos poderes estaduais, traçando-lhes principios, a que deverão necessáriamente se adstringir, tais como a vitaliciedade e a inamovibilidade dos Magistrados, a irredutibilidade de seus vencimentos, a incompatibilidade da Magistratura com o exercício de qualquer outra função pública, a investidura dos primeiros gráus mediante concurso organizado pelo Tribunal de Apelação, a investidura nos gráus superiores mediante promoção por antiguidade e por merecimento, etc.

Aos dez princípios que a Constituição taxativamente enumera em seus artigos 103, devemos acrescentar o do artigo 105 relativo à participação de um quinto de advogados ou de membros do Ministério Público na composição dos Tribunais de Apelação, e mais os dos artigos 107, 108 e 109, sôbre a competência dos Juizos das Capitais dos Estados nas causas propostas pela União ou contra ela, o recurso direto respectivo para o Supremo Tribunal, etc..

Por conseguinte, em matéria de organização judiciária, prevalece o princípio da competência exclusiva dos Poderes Estaduais dentró dos limites claramente traçados pela Constituição. Além dessas restrições constitucionais, - que atendem, quer à garantia e à dignidade da Magistratura, quer a altos interesses da União, - nenhuma outra sofrem os Estados, só podendo surgir outras mediante leis federais especiais de caráter constitucional Assim sendo, ainda que - Código de Processo Civil contivesse dispositivos que implicassem em restrições à autonomia estadual relativamente à organização de sua Justiça, deveria prevalecer o texto constitucional.

É claro que está assim assegurado pela Carta Constitucional o' direito dos Estados de criar Justiça de paz, mesmo eletiva, desda que haja recurso aos Juizes togados de suas decisões. Assim sendo 
os artigos 839 e 840 do estatuto processual não impedem a soluçãa que aventamos. A luz do claro dispositivo constitucional acima citado, ou concluimos pela inconstitucionalidade dos artigos 839 e 840 do Código de Processo ou é necessário interpretálos como despaz com alçada ou de resolverem atribuir aos juizes de paz competência para julgar ações de valor inferior a $500 \$ 000$, como é aconselhavel. Nas ações de valor superior a 500\$000 até $21: 000 \$ 000$ aplicar-se-ia integralmente o Código de Processo.

Nem é admissível a teoria daqueles que dizem que o Código de Processo, lei federal que é, revogou o citado texto da Constituição. A distinção entre leis constitucionais e leis ordinárias continua a ser fundamental, de maneira que, com apôio na Constituição, poderão os Estados criar livremente a Justiça da paz fixando a sua competência, não obstante os infelizes dispositivos da lei processual, desde que se estabeleça recurso à Justiça togada. 